Military Technical College

Kobry El-Kobbah,

Cairo, Egypt

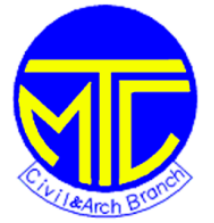

\title{
INVESTIGATING MEASURES TO INCREASE THE LIFESPAN OF CONCRETE COASTAL STRUCTURES IN THE NILE DELTA
}

\author{
Omar A. Elnawawy \\ Prof. Structural Eng. \\ department \\ Ain shams university
}

\author{
Goda A.Atia \\ Structural Eng. \\ department \\ Zagazig university
}

\section{$10^{\text {th }}$ International Conference on Civil and Architecture Engineering}

ICCAE-10-2014

\author{
El-Serafy, S \\ Prof., Hydraulics and \\ Irrigation department \\ Ain Shams University
}

\author{
Omar K.Abdeen \\ Eng., Structural Eng. \\ department \\ Ain shams university
}

\begin{abstract}
In terms of the importance of enhancing concrete coastal structures exposed to chlorides, this study was initiated with the objective of increasing their lifespan. Two measures were proposed (i.e. to increase the thickness of the concrete cover oradd Carbon Fiber Reinforced Polymer (CFRB) sheets).27 R.C. specimens were investigated experimentally. The specimens were exposed to variable sodium chlorideratios by weight "salt cement ratio"(s/c) (i.e. 3:100 “3\%”, 3:50 “6\%" and 1:10 “10\%”). The specimens were prepared, cured, dried and tested. The Zagazig Structural Laboratory was set. Measuring devices were fixed and measurements were undertaken. Also, photos were captured and observations were documented. The strains, cracking load and cracking pattern were determined.The undertaken measurements, the shot photos and documented observations were analyzed; graphs relating the different parameters were plotted and were presented. It was found that these enhancement measures improved the behavior of the concrete specimens subjected to Chlorides which would most probably extend the lifespan of concrete coastal structures.

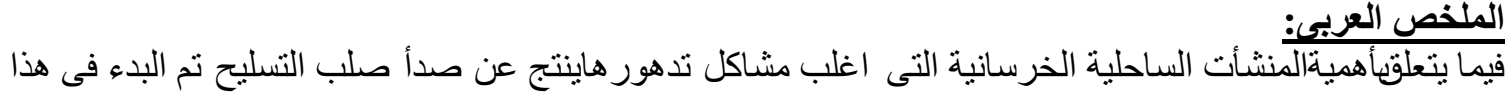

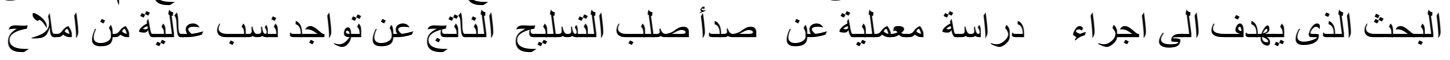




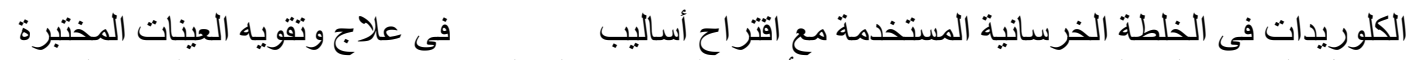

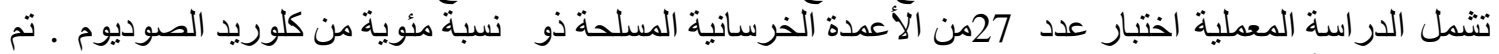

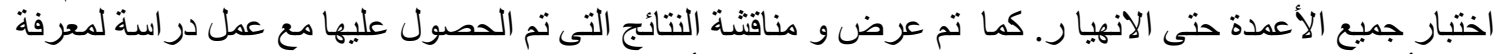

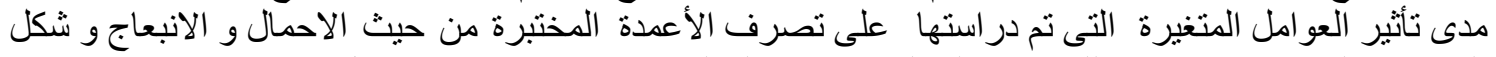

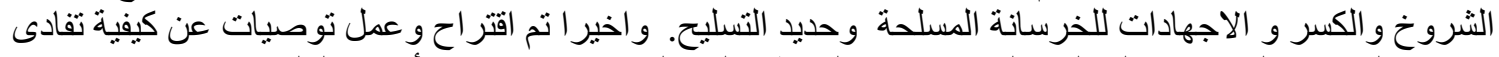

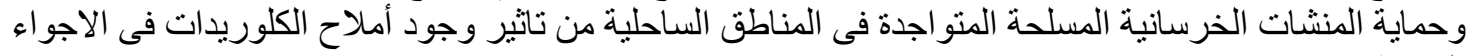
المحيطة. 


\section{INTRODUCTION}

Up-and-coming problems, facing the low-lying lands, necessitate the implementation of extra concrete coastal protection measures. Due to their high construction cost, durable structures with longer lifespan are required. This is attributed to the fact thatconcreteis mainly damaged by sea water effects and chemical damage (i.e. from chlorides). This process adversely affects concrete exposed to these damaging stimuli. The expansion of the corrosion products (iron oxides) of carbon steel reinforcement inducesmechanical stress that can cause the formation of cracks and disrupt the concrete coastal structures.Flat fragments of concrete are detached from the concrete mass and may fall down.

In terms of the importance of constructing longer lifespanconcrete coastal structures, this research was initiated. The main objectives were to propose and examine the efficiency of the measuresto enhance the structural behavior of coastal concrete structures (i.e. columns) when exposed to high percentages of sodium chloride. Additionally,the research aimed to determine the strain in steel so as strain of concrete, the buckling and the cracking so as ultimate loads of the enhancedspecimens.

In order to achieve the above objectives, a methodology was planned. Themethodology phases were to assemble available literature in the field of concrete degradation and enhancement methods; propose enhancement measures; design an experimental program; prepare specimens; adjust measuring devices; execute tests varying the s/c ratio; undertake measurements; analyze the measurements, plot the results; interpret themand provide conclusions so as recommendations for further research.

\section{PROBLEM DEFINITION}

In the Nile Delta in Egypt, likewise in all low-lying lands all over the world, there is an emergent need to construct extra coastal structures to face the up-and coming problems.Additionally, there is an urgent need to enhance the coastal structures endurance to withstand the great challenges of the near future and to possess a longer lifespan. This is attributed to the fact that the low-lying lands in coastal zonesare confronted by many challenges that would need plenty of extra coastal protection measures. Among these challenges are:

- $\quad$ Global warming and sea level rise:Effects of global warming are long-term significant changes in the expected patterns of average weather of any coastal region. The world average temperature would rise due to the greenhouse effect caused by increasing levels of carbon dioxide. This would cause melting of ice, changing the hydrological cycle (of evaporation and precipitation) and changing currents in the seas and air flows in the atmosphere. Consequently, the coasttogether with the coastal structures would suffer from the severe impacts ofsea level rise.Global sea level is currently rising due to the thermal expansion of water in the oceans and the addition of water from ice sheets. Consequently, the low-lying coastal areas (i.e. Nile Delta), many of which are heavily populated, are at risk of flooding.The IPCC (2007) projected that by the 2080s, millions of people would experience floods every year due to sea level rise. This would necessitate theimportance of constructing more coastal durable protection structures. 
- Wave action: The wave action induces coastal sediment movements that cause shoreline changes.This might also acquire more protection works.

- $\quad$ Land subsidence:Subsidence is the motion of a surface as it shifts downward relative to a datum such as sea-level. Ground subsidence is of concern to coastal engineers, geologists, geotechnical engineers and surveyors. The subsidence of land typically occurs to low-lying lands such as the Nile Delta.This might also acquire extra protection works.

- Exposure to Chlorides:Concrete is mainly damaged by sea water effects and chemical damage (i.e. from chlorides). This process adversely affects concrete exposed to these damaging stimuli. The expansion of the corrosion products (iron oxides) of carbon steel reinforcement induces mechanical stress that can cause the formation of cracks and disrupt the concrete coastal structures. Flat fragments of concrete are detached from the concrete mass and may fall down.This might also acquire additional protection works.

Many other factors contribute in coastal zone changes which necessitates the establishment of extra coastal structures which by their turn need to be enhanced to face the oncoming conditions. Consequently, measures should be proposed to enhance the behavior of the coastal structures which usually deteriorates thus causing their failure.

\section{REVIEWING THE LITERATURE}

Published reports, periodicals and articles in scientific journals were assembled, reviewed, analyzed and comprehended. Based on the revised literature, it was found that many researchers are involved in investigating long-term durable concrete that could be safely implemented in marine structures, IPCC (2001) and (2007).

Based on this revision, the different investigated aspects were analyzed and categorized into groups. These groups covered coastal structures attacked by chlorides, corrosion effects on concrete, chloride-induced corrosion, factors affecting chloride resistance, chloride resistance tests, indirect measures, theoretical studies, experimental studies, extraction of chlorides, numerical modeling, thermal cracking, finite element numerical models, corrosion staining in concrete and minimizing corrosion of steel, Koch et al (2002), Zhang et al. (2002) and Tang et al. (2012).

The assembled literature indicated that corrosion and its effect on concrete, chlorideinduced corrosion, factors affecting chloride resistance, chloride resistance tests, indirect measures, theoretical studies, extraction of chlorides, numerical modeling, thermal cracking, finite element numerical models, corrosion staining in concrete and minimizing corrosion of steel are methodically and logically mentioned in the assembled literature. It also indicated that the experimental investigations are not meticulously enclosed in the available literature and are bounded by some discrepancies which mean that more investigations are required. Therefore; it was decided to go further and execute experimental work.

\section{PROPOSING ENHANCEMENT METHODS}

It was thought that if the bars are properly installed and are located away from the concrete surface in contact with the air, damage could not occur easily. Additionally, it was further perceived that if the steel bars are protected by Carbon Fiber Reinforced Polymer (CFRP) sheets. CFRP is a Polymer Matrix Composite material reinforced by 
carbon. It has alow densityof $114 \mathrm{lb} / \mathrm{ft}^{3}\left(\mathrm{i} . e .1800 \mathrm{~kg} / \mathrm{m}^{3}\right.$ ). Consequently, steel damage could not occur easily.

Accordingly, two measures were proposed:

- The first measure was to increase the thickness of the concrete cover.

- The second measure was to introduce CFRP sheets to the specimens.

\section{DESIGNING AN EXPERIMENTAL PROGRAM}

An experimental program was designed. It encompassed 27 specimens(i.e. S1 to S27) that were divided into 3 groups (i.e. Group I, II and III), each encompasses 9 specimens (i.e. columns). The second and third groups were enhanced either by increasing the thickness of the concrete cover or introducing CFRP sheets to the specimens.

It is to be noted that the tested cross section was $200 \mathrm{x} 200 \mathrm{~mm}$. The steel reinforcement was 4 $₫ 12$. The concrete cover was taken as $25 \mathrm{~mm}$ except for the enhanced groups; it was taken as $40 \mathrm{~mm}$. The salt cement ratio, by weight was $3 \%, 6 \%$ and $10 \%$, Table (1).

\section{INSPECTING THE MATERIALS}

The specimens were prepared from cement, salt (i.e. Sodium Chloride), water, reinforcement bars and water. The cement used in this study was locally manufactured Ordinary Portland Cement, photo (1). Upon delivery, the cement was emptied into plastic sacks and then stored in dry air in the laboratory. This was achieved in order to minimize the deterioration of cement during the investigations.The fine agqreqate, photo (2), was dry natural sand and the coarse aggregate consisted of a mixture of rounded and crushed gravel with $20 \mathrm{~mm}$ maximum nominal size. Coarse aggregate was washed by water to dissolve any salts in the aggregate.Sodium Chloride salt was implemented as a source of chloride ions, photo (3). In order to avoid the effects of different chloride ions diffusion rates due to different cation, the salts were added to concrete by dissolving the different quantities as ratios (3:100, 3:50 and 1:10) (i.e. 3\%, $6 \%$ and 10\%) by weight of cement in mixing water before casting. The salt was stored in plastic sacks at dry air in the laboratory before using. The used steel was $12 \mathrm{~mm}$ diameter deformed high tensile and 8 $\mathrm{mm}$ normal mild steel as main longitudinal reinforcement and shear stirrups, respectively. Tension tests were carried out on three specimens of each type.

The mechanical properties of the implemented materials were tested and were determined. They all fell within the allowable values prescribed in the Egyptian Code of Practice.

\section{PREPARING THE SPECIMENS}

Themixing procedures of the unenhanced and enhanced specimens were carried out in the laboratory mixer, photo (4). The mixing process proceeded as follows:

1. The materials were mixed dry for two "2" minutes.

2. Water was added gradually to the dry mix and was moved persistently until a uniform color and shape were obtained to the control specimens. The salty mixing water with different percentage $s / c=3,6,10 \%$ was added gradually to the unenhanced and enhanced specimens and mixing was continued until a uniform color so as shape were obtained.

3. In the prepared wooden formworks, photo (5), the concrete was cast over the steel reinforcement, photo (6). 
4. Concrete columns were mechanically vibrated for one minute.

5. Formworks were removed after 24 hours and were subjected to natural air and wet spray to cure it, photo (7), on daily basis for 28 days after casting.

\section{SETTING THE LABORATORY AND FIXING THE MEASURING DEVICES} After investigating the materials and preparing the specimens, the Structural Laboratory in ZagazigUniveristy, Faculty of Engineering, was set in order to inspect the prepared specimens.

The laboratory is equipped with a loading machine (i.e. loading frame, hydraulic universal machine), photo (8). The specimens were prepared in the laboratory and placed on the loading frame to be inspected and the designed test program was achieved.

Columns were loaded by load cell symmetrically at two "2" points over an effective span of $50 \mathrm{~cm}$. Two Linear Variable Differential Transducer (LVDT) gauges were used to measure the deflection, one of them under the load and the second at the mid span of the column. Concrete strain gauges were used to measure strain of concrete, and steel strain gauges were used to measure strain of steel. All gauges were connected to the data logger to read measurements.The measuring devices (i.e. strain gauges) were fixed on the prepared specimens after being cured and dried. The strain gauges were arranged as shown in photo (9).

\section{UNDERTAKING MEASUREMENTS}

After fixing the measuring devices, measurements were undertaken. These measurements were strain in steel so as concrete together with loads corresponding to crack, yield and ultimate loads. Deflection measurements were undertaken, as well. Also, crack patterns were photographed.

The strain of steel was measured at the middle of the main steel bar (within the tension zone). The gauges $(10 \mathrm{~mm})$ were connected to a data logger.

The strain of concrete was measured at the middle of the upper face of columns (at the compression zone) by fixing the strain gauge $(20 \mathrm{~mm})$ to the concrete. The gauges were connected to the data logger.

Loads were recorded by the data logger with an increasing increment of $2 \mathrm{KN}$ until the first crack appears (i.e. first crack load), yield occurred (i.e. yield load) and crushing occurred (i.e. ultimate load). Photo (10) is provided to indicate the specimens during testing.

The deflection was measured at three points, the first at mid span of columns, the second and third points were measured under the acting loads.

Cracks were tracked, traced and sketched on the column during loading to reach failure. Photos were shot to capture the shapes of cracks. Notes were recorded to identify kind of failure.

\section{ANALYZING THE RESULTS AND PRESENTING THEM}

The undertaken measurements, the shot photos and documented observations were analyzed.Graphs relating the different parameters were plotted. Only a sample is presented here, figures (1) to (9).This sample was tested with $10 \% \mathrm{~s} / \mathrm{c}$ ratio. It was chosen as it has the highest tested salt cement ratio in order to indicate the results clearly. 
Figures (1) to (3) represent the relation between the loads and buckling for the unenhanced specimens and enhanced specimens with $40 \mathrm{~mm}$ cover or with CFRP sheets, respectively.Figures (4) to (6) represent the relation between the loads and strain of steel for the unenhanced and enhanced specimens with $40 \mathrm{~mm}$ cover or with CFRP sheets, respectively. Figures (7) to (9) represent the relation between the loads and strain of concrete for the unenhanced and enhanced specimens with $40 \mathrm{~mm}$ cover or with CFRP sheets, respectively.

Although the curves are self-explanatory curves, a comparison to the values of buckling, strain of steel and strain of concrete of the unenhanced specimens, enhanced specimens with $40 \mathrm{~mm}$ cover and enhanced specimens with CFRP sheets is given in table (2). It is to be noted that these values are a load of $400 \mathrm{KN}$ (i.e. average load). The table also provides the enhancement percentage due to the provided extra concrete cover or the addition of CFRP.

Where:

Enhancement percentage $=$

[Value of unenhanced specimen -Value of the enhanced specimen] x 100

Value of unenhanced specimen

Also, photos (11) and (12) are given to illustrate the failure modes of unenhanced and enhanced specimens, respectively.

\section{CONCLUSIONS AND RECOMMENDATIONS}

Based on the executed experiments, $\underline{\text { conclusions }}$ were reached. The deduced conclusions are presented here, as follows:

- The unenhanced concrete specimens behaved differently from the enhanced specimens when they were exposed to chlorides.

- The unenhanced concrete specimens were easier to crush and crack at higher s/c ratio.

- The enhancedspecimenexperienced relatively lowerbucklingthan the unenhanced specimens(i.e. enhancement percentage at $400 \mathrm{KN}=6$ to $28 \%$ ).

- The enhanced specimensexperienced relatively less strain of steel than the unenhancedspecimens(i.e. enhancement percentage at $400 \mathrm{KN}=45$ to $65 \%$ ).

- The enhanced specimens experiencedless strain of concrete than the unenhanced specimens(i.e. enhancement percentage at $400 \mathrm{KN}=18$ to $32 \%$ ).

- If the bars are poorly installed and are located near the concrete surface in contact with the air, cracks and damage could easily occur.

- The lifespan of coastal structures most probably would be extended if the steel bars are properly located away of the concrete surface or protected by CFRP sheets.

- It is better to implement CFRP sheets as an enhancement measure ((i.e. enhancement percentage at $400 \mathrm{KN}=23$ to $65 \%$ ).

Based on the achieved experiments, recommendations were prolonged. The extended recommendations are presented here, as follows:

- As for the coastal engineering practice, one should mention that: 
$\checkmark$ Bars should be properly installed and should be located away from the concrete surface in contact with the air in order to ensure damage delay.

$\checkmark$ Measures should be undertaken while constructing any coastal structure.

$\checkmark$ Among these measures are increasing the concrete cover to protect the reinforcing steel or adding CFRP sheets to safeguard the steel bars.

- Regarding the coastal engineering research, one should further advise researchers to:

$\checkmark$ Investigate other measures that could be undertaken during constructing coastal structures (i.e. FRP rebar or FRP).

$\checkmark$ Inspect these measures to safeguard the steel bars, using different concrete elements (i.e. beams and piles).

\section{LIST OF REFERENCES}

1. Concrete Repair Manual (2003): "ACI International, BRE, Concrete society, and International Concrete Repair Institute (ICRI)", Second edition, Vol. 1, May 2003.

2. H.T. Cao et al. (1993): "Corrosion rates of steel embedded in Cement pastes", Cement and Concrete Research 23 (1993), pp. 1273-1282.

3. IPCC (2001):IPCC Third Assessment Report: Climate Change 2001 (TAR)

4. IPCC (2007):IPCC Fourth Assessment Report: Climate Change 2007 (AR4)

5. G.H. Koch et al. (2007): "Corrosion Costs and preventive strategies in the United States, Publication No. FHWA-RD- 01-156, NACE International Houston TX, USA, 2002.

6. J.K. Boah et al. (1990): "Electro chemical behavior of steel in Saturated calcium hydroxide solution containing SO4-2 and $\mathrm{CO}_{3}{ }^{-2}$ ions”, Corrosion 46 (1990), pp. 153158.

7. J.P. Broomeld (2007): "Corrosion of steel in concrete" understanding investigation and repair, $2^{\text {nd }}$ edition, Taylor and Francis,NewYork, 2007.

8. Page, C. L. et al. (1982): "Aspects of Electrochemistry of steel in concrete- Nature" Vol. 297, 1982, pp. 109-115.

9. Syed Ayub (2005):"A Prediction Model For The Residual Flexural Strength of Corroded Reinforced Concrete Beams” A thesis in Partial Fulfillment of the Requirements for the Degree of Master of Science in Civil Engineering - Faculty of Engineering -King Fahd University of Petroleum \& Minerals - 2005.

10. Schutt, W. R. (1992): "Cathodic Protection of New High- Rise Buildings in AbuDhabi,” Concrete International, May 1992, pp. 45-46.

11. Tang et al (2012):"Corrosion resistance and mechanism of steel rebar coated with three types of enamel” Corrosion Science (2012).

12. Zhang et al. (2009): "The corrosion pattern of reinforcement and its influence on service ability of reinforced concrete members in chloride environment" Cement and Concrete Research, 39 (2009), pp. 1077-1086. 


\begin{tabular}{|c|c|c|c|c|c|c|}
\hline $\begin{array}{l}\text { Specimens } \\
\text { Identification }\end{array}$ & $\begin{array}{l}\text { Main } \\
\text { (CFRP) }\end{array}$ & $\begin{array}{c}\text { cross } \\
\text { section } \\
(\mathbf{m m})\end{array}$ & $\begin{array}{l}\text { Cover } \\
(\mathrm{mm})\end{array}$ & $\begin{array}{l}\text { salts to } \\
\text { cement } \\
\text { ratio } \\
\text { (by } \\
\text { weight) }\end{array}$ & $\begin{array}{l}\text { Exposure } \\
\text { Period } \\
\text { (days) }\end{array}$ & $\begin{array}{c}\text { Type of } \\
\text { Specimen }\end{array}$ \\
\hline
\end{tabular}

Table (1) Designed test program 


\begin{tabular}{|c|c|c|c|c|c|c|}
\hline 1 & \multirow{3}{*}{$\begin{array}{c}4 \varnothing 12 \\
(---)\end{array}$} & \multirow{3}{*}{$200 \times 200$} & \multirow{3}{*}{25} & \multirow{3}{*}{$3 \%$} & ---- & Control \\
\hline S2 & & & & & 180 & Unenhanced \\
\hline S3 & & & & & 365 & Unenhanced \\
\hline S4 & \multirow{3}{*}{$\begin{array}{c}4 \emptyset 12 \\
(---)\end{array}$} & \multirow{3}{*}{$200 \times 200$} & \multirow{3}{*}{25} & \multirow{3}{*}{$6 \%$} & ---- & Control \\
\hline S5 & & & & & 180 & Unenhanced \\
\hline S6 & & & & & 365 & Unenhanced \\
\hline S7 & \multirow{3}{*}{$\begin{array}{c}4 \varnothing 12 \\
(---)\end{array}$} & \multirow{3}{*}{$200 \times 200$} & \multirow{3}{*}{25} & \multirow{3}{*}{$10 \%$} & ---- & Control \\
\hline S8 & & & & & 180 & Unenhanced \\
\hline S9 & & & & & 365 & Unenhanced \\
\hline S10 & \multirow{3}{*}{$\begin{array}{c}4 \varnothing 12 \\
(---)\end{array}$} & \multirow{3}{*}{$200 \times 200$} & \multirow{3}{*}{40} & \multirow{3}{*}{$3 \%$} & ---- & Control \\
\hline S11 & & & & & 180 & Enhanced \\
\hline S12 & & & & & 365 & Enhanced \\
\hline S13 & \multirow{3}{*}{$\begin{array}{c}4 \emptyset 12 \\
(---)\end{array}$} & \multirow{3}{*}{$200 \times 200$} & \multirow{3}{*}{40} & \multirow{3}{*}{$6 \%$} & ---- & Control \\
\hline S14 & & & & & 180 & Enhanced \\
\hline S15 & & & & & 365 & Enhanced \\
\hline S16 & \multirow{3}{*}{$\begin{array}{c}4 \varnothing 12 \\
(---)\end{array}$} & \multirow{3}{*}{$200 \times 200$} & \multirow{3}{*}{40} & \multirow{3}{*}{$10 \%$} & --- & Control \\
\hline S17 & & & & & 180 & Enhanced \\
\hline S18 & & & & & 365 & Enhanced \\
\hline S19 & \multirow{3}{*}{$\begin{array}{c}4 \emptyset 12 \\
\text { (Sheets) }\end{array}$} & \multirow{3}{*}{$200 \times 200$} & \multirow{3}{*}{25} & \multirow{3}{*}{$3 \%$} & & Control \\
\hline S20 & & & & & & Enhanced \\
\hline S21 & & & & & & Enhanced \\
\hline S22 & \multirow{3}{*}{$\begin{array}{c}4 \varnothing 12 \\
\text { (Sheets) }\end{array}$} & \multirow{3}{*}{$200 \times 200$} & \multirow{3}{*}{25} & \multirow{3}{*}{$6 \%$} & & Control \\
\hline S23 & & & & & & Enhanced \\
\hline S24 & & & & & & Enhanced \\
\hline S25 & & & & & & Control \\
\hline S26 & $4 \emptyset 12$ & $200 \times 200$ & 25 & $10 \%$ & & Enhanced \\
\hline S27 & (Sheets) & & & & & Enhanced \\
\hline
\end{tabular}




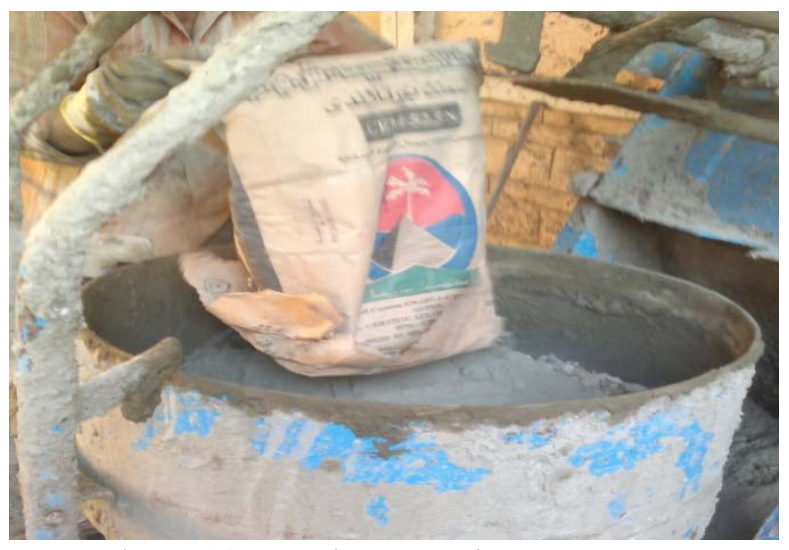

Photo (1) Implemented cement sacs



Photo (2) Implemented aggregate



Photo (3) Sodium chloride sacs 

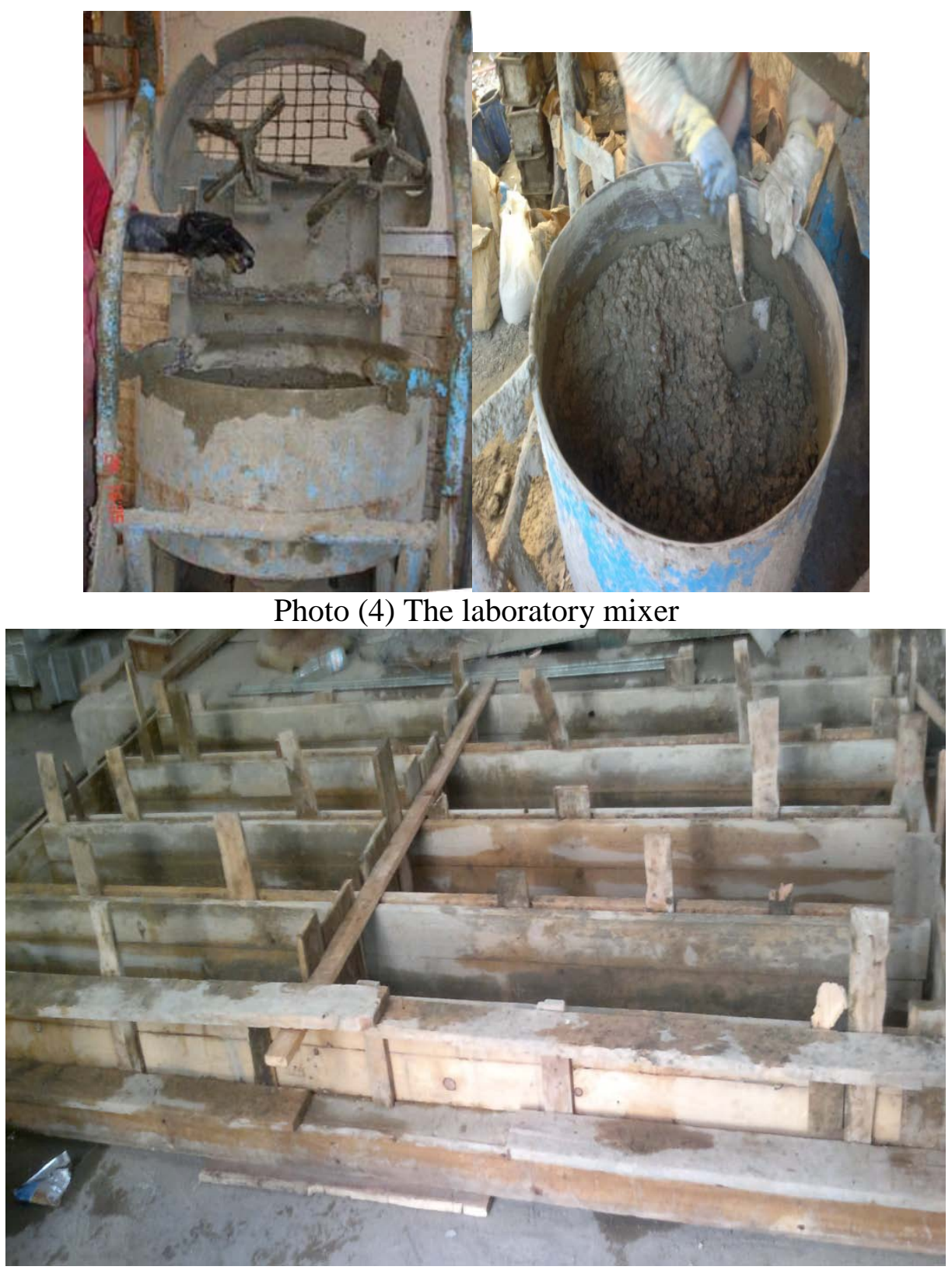

Photo (5) Wooden formworks

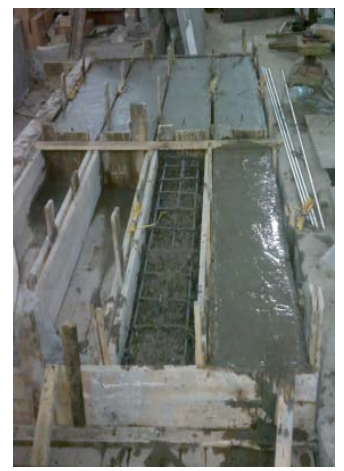

Photo (6) Casting concrete over steel in formworks 


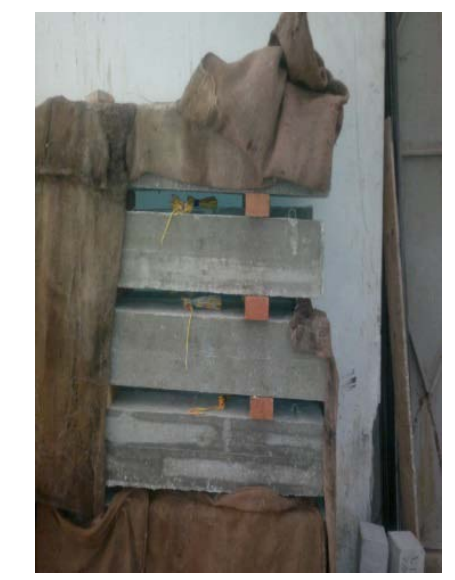

Photo (7) Spray wet curing

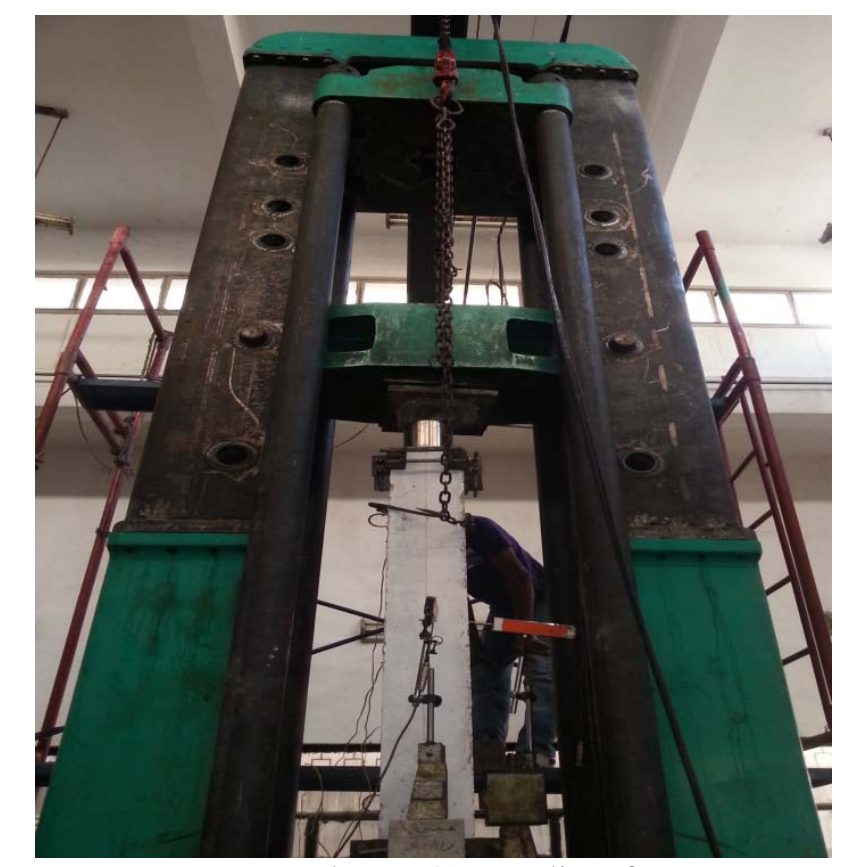

Photo (8) Loading frame



Photo (9) Strain gauges 


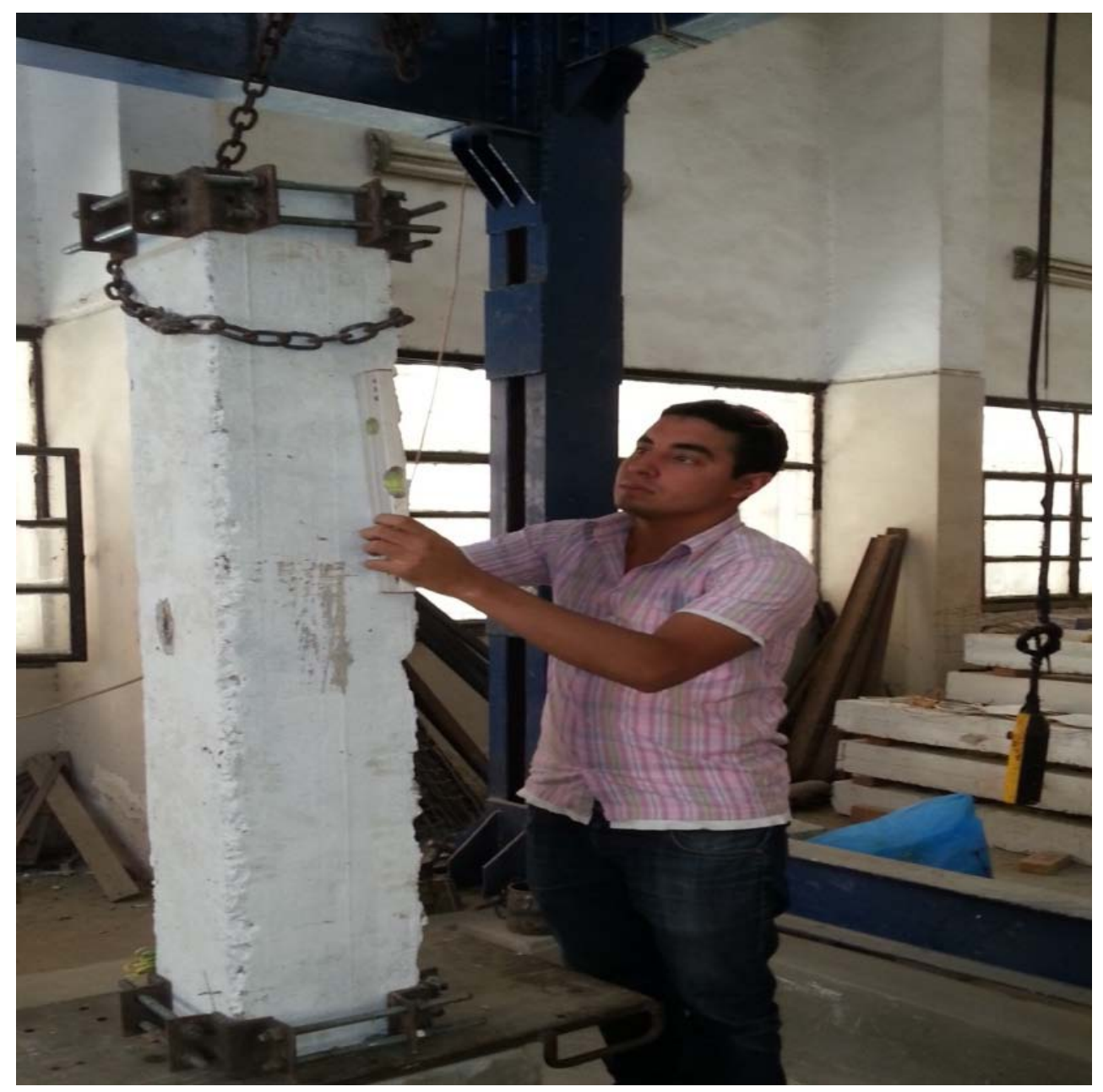

Photo (10) Specimens during testing 




Figure (1) Relation between load and buckling (Unenhanced)

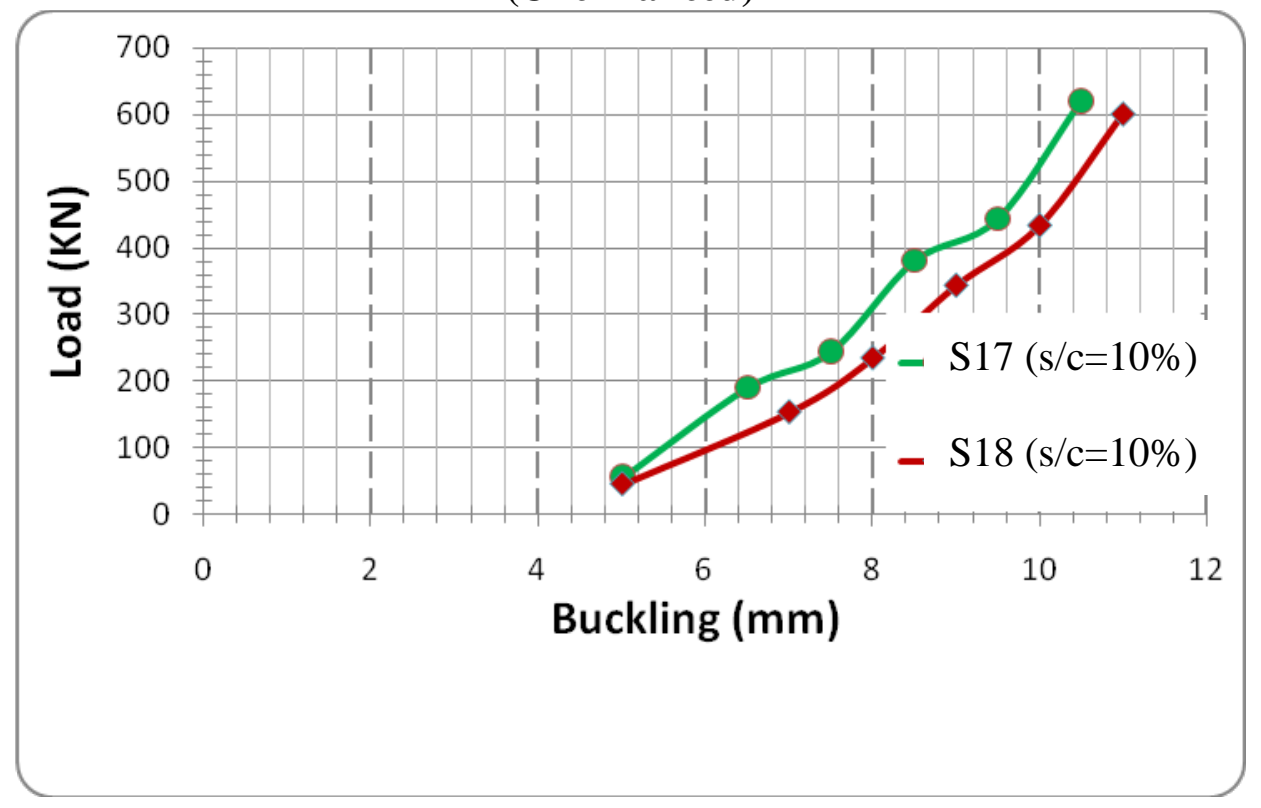

Figure (2) Relation between load and buckling (Enhanced specimens with $40 \mathrm{~mm}$ cover) 


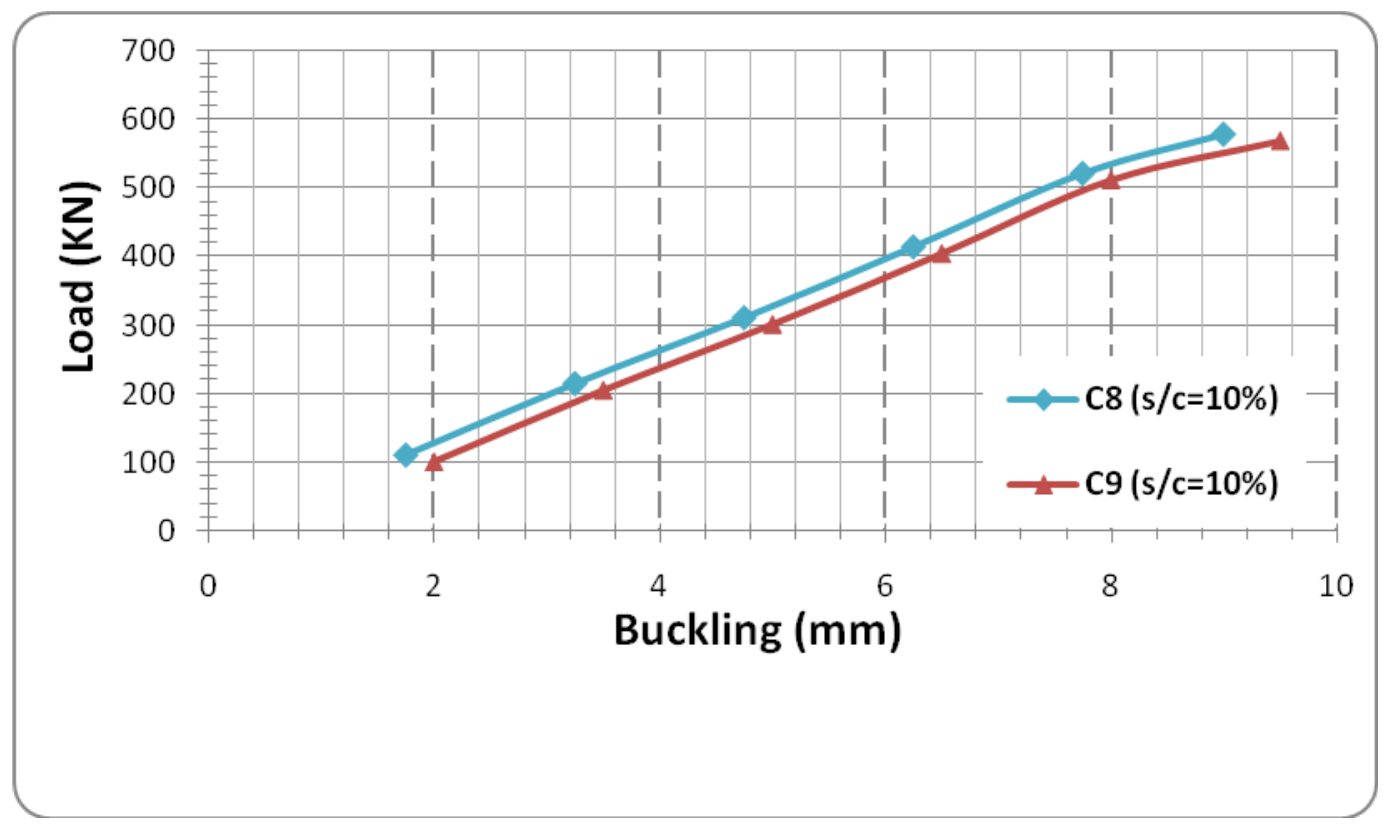

Figure (3) Relation between load and buckling (Enhanced specimens with CFRP)

$$
\begin{aligned}
& \text { S26 (s/c=10\%) } \\
& \text { S27 (s/c=10\%) }
\end{aligned}
$$




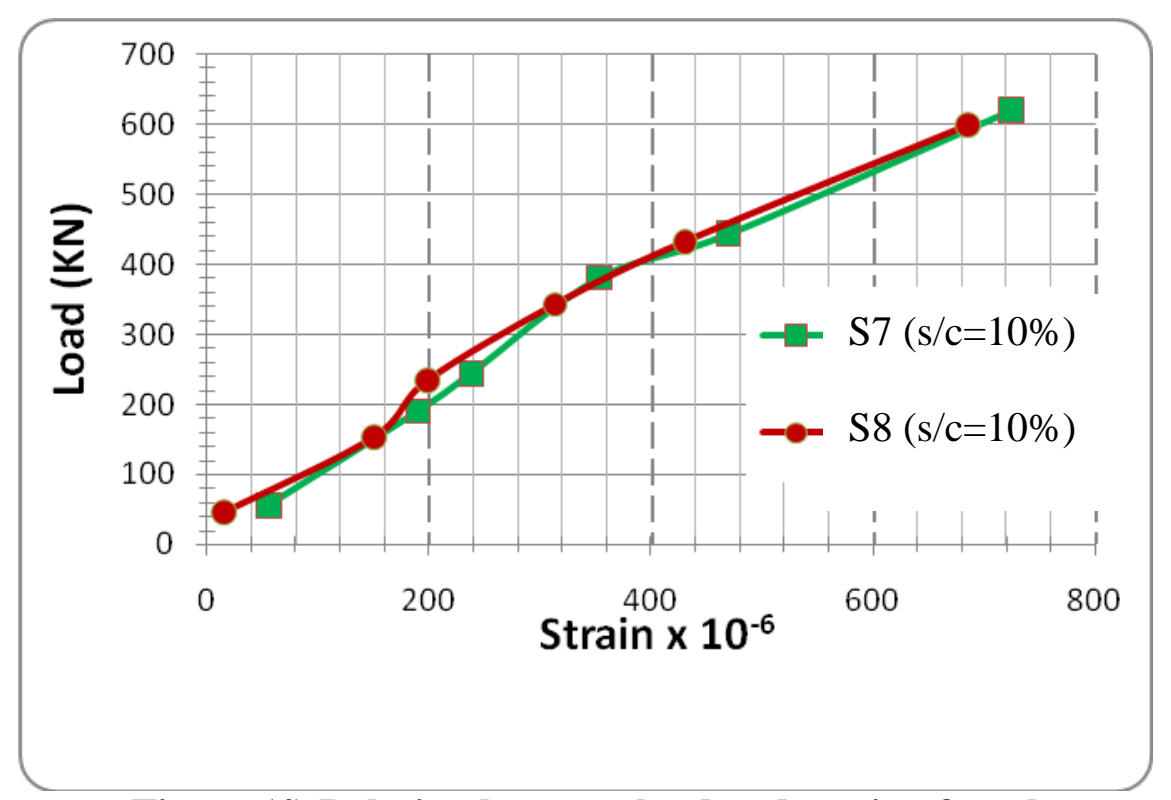

Figure (4) Relation between load and strain of steel (Unenhanced specimens)

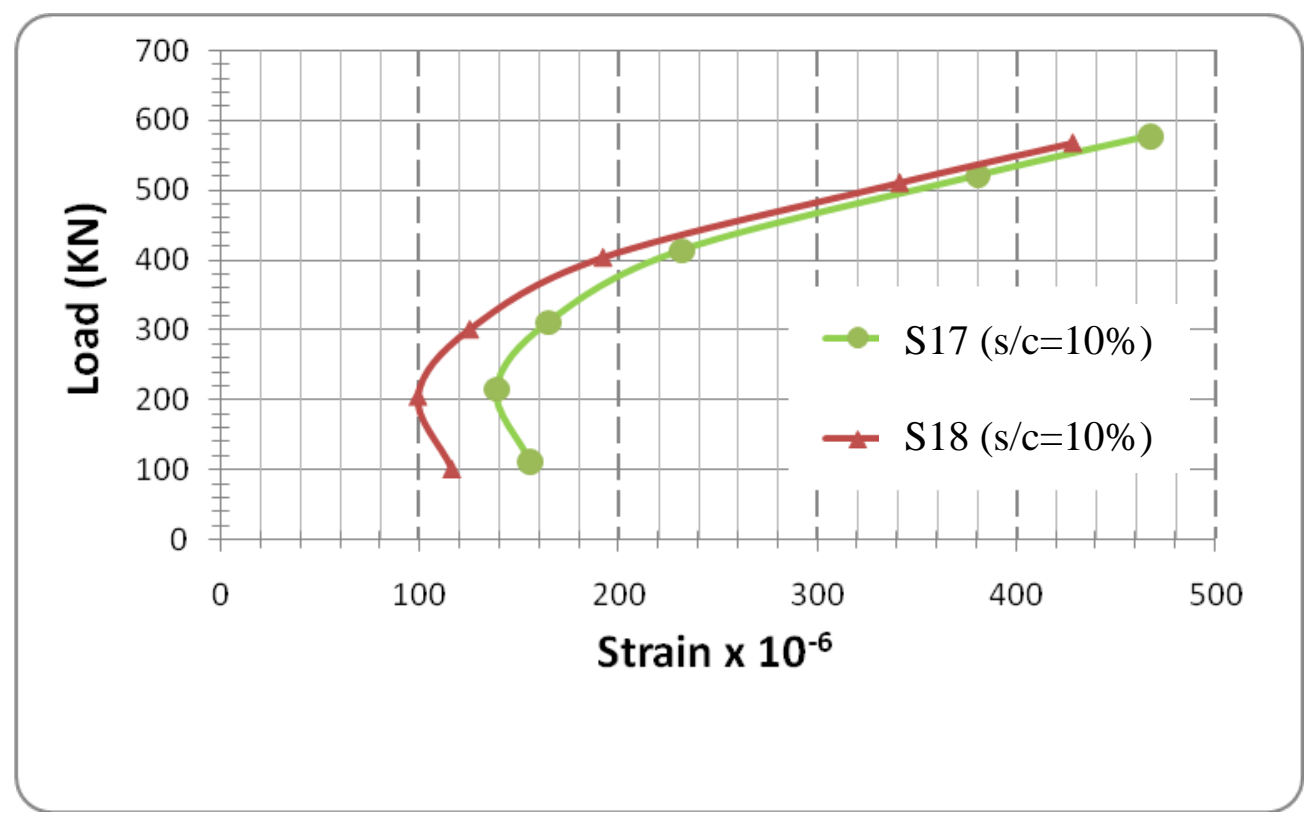

Figure (5) Relation between load and strain of steel (Enhanced specimens with $40 \mathrm{~mm}$ cover) 


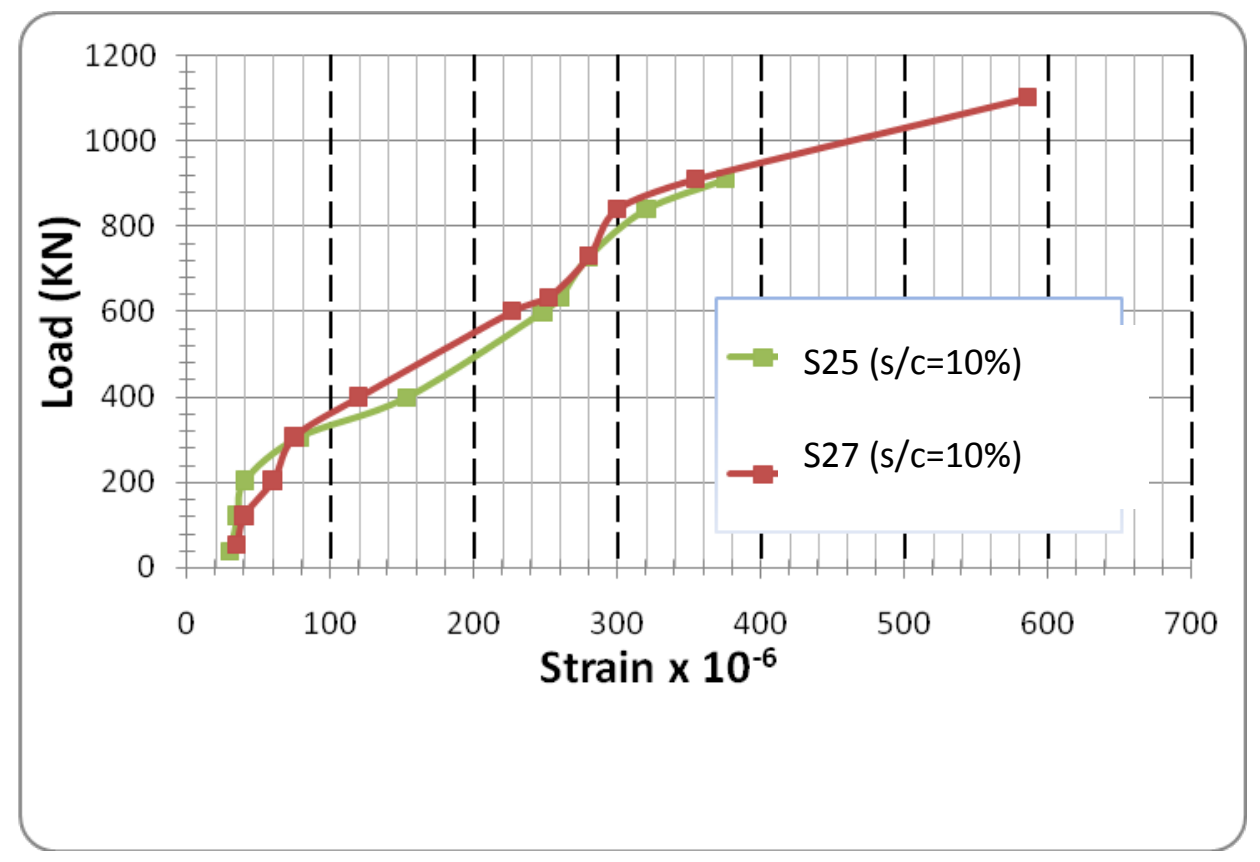

Figure (6) Relation between load and strain of steel (Enhanced with CFRP sheets) 


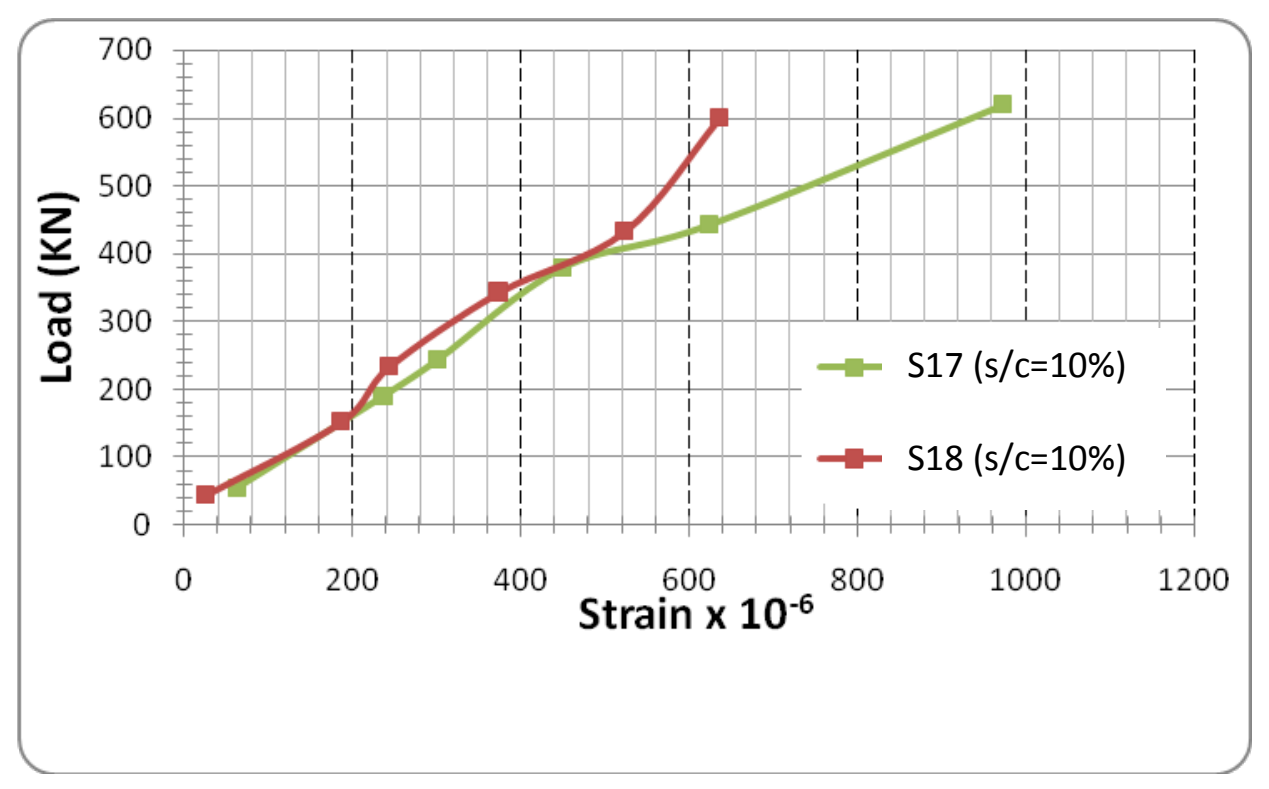

Figure (7) Relation between load and strain of concrete (Unenhanced)

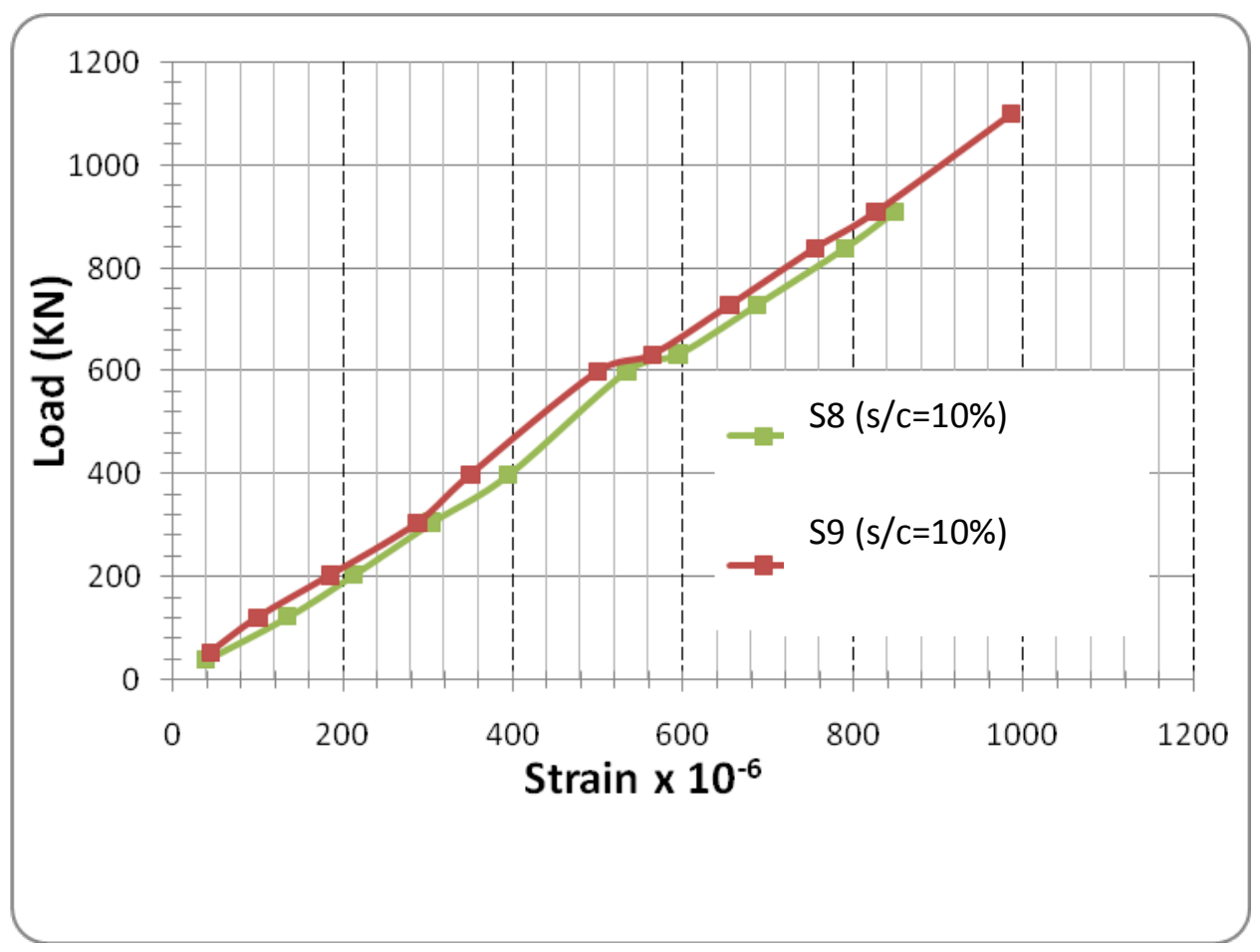

Figure (8) Relation between load and strain of concrete (Enhanced with $40 \mathrm{~mm}$ cover) 


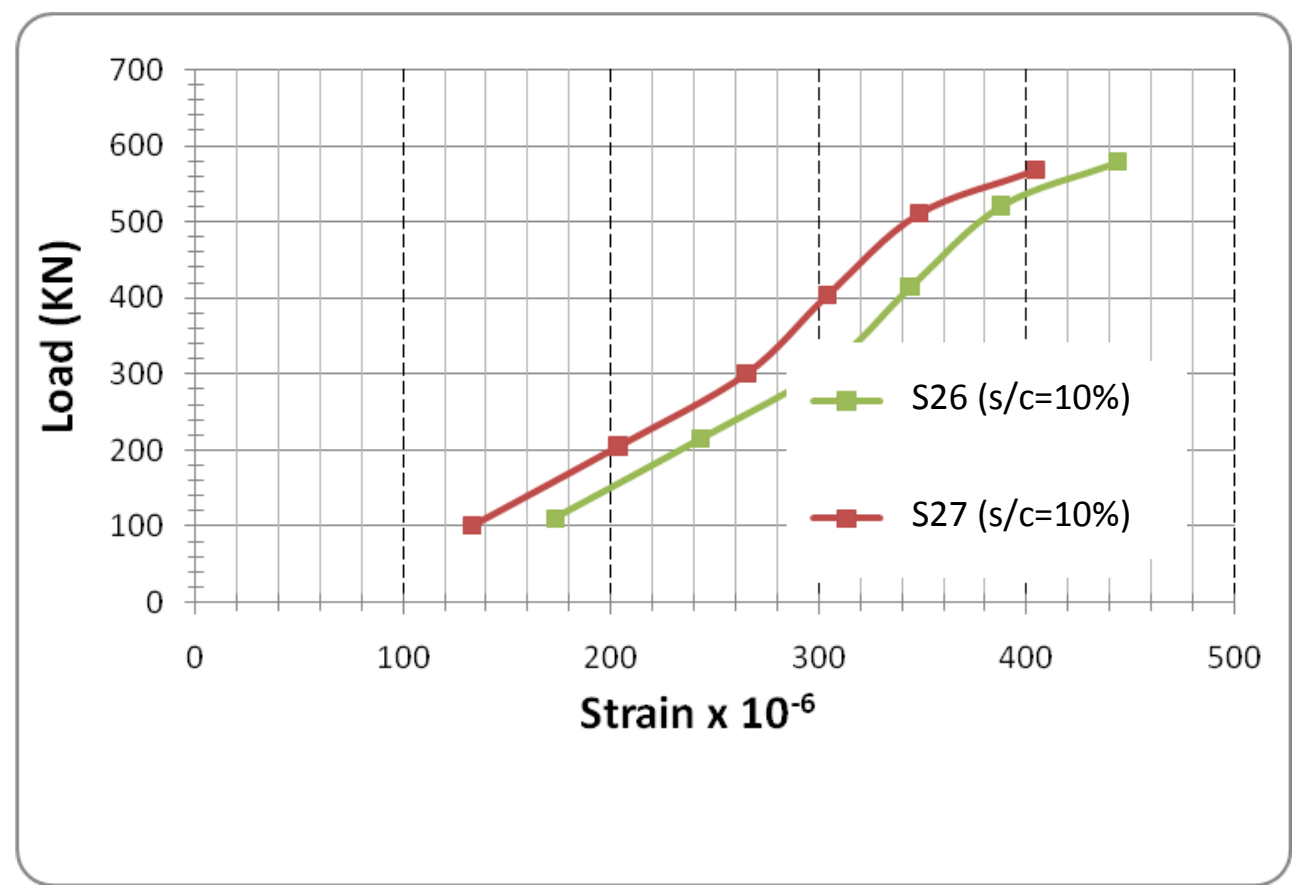

Figure (9) Relation between load and strain of concrete (Enhanced specimens with CFRP)

Table (2) Values of buckling, strain of steel and strain of concrete of the unenhanced specimens, enhanced together with the enhancement percentages

\begin{tabular}{|c|c|c|c|}
\hline Specimen type & Unenhanced & $\begin{array}{c}\text { Enhanced with } 40 \\
\text { mm cover }\end{array}$ & $\begin{array}{c}\text { Enhanced with } \\
\text { CFRP sheets }\end{array}$ \\
\hline $\begin{array}{c}\text { Buckling } \\
\text { (mm) }\end{array}$ & 9.6 & 8.4 & 6.0 \\
\hline $\begin{array}{c}\text { Enhancement } \\
(\%)\end{array}$ & -- & 12.5 & 37 \\
\hline $\begin{array}{c}\text { Strain of steel } \\
\times 10^{-6} \mathrm{~mm}\end{array}$ & 440 & 200 & 160 \\
\hline $\begin{array}{c}\begin{array}{c}\text { Enhancement } \\
(\%)\end{array} \\
\end{array}$ & - & 54 & 63 \\
\hline $\begin{array}{l}\text { Strain of concrete } \\
\quad \times 10^{-6} \mathrm{~mm}\end{array}$ & 360 & 320 & 300 \\
\hline $\begin{array}{c}\text { Enhancement } \\
(\%)\end{array}$ & - & 11 & 16 \\
\hline
\end{tabular}






Photo (11) Mode of Failure for one of the unenhanced specimens 

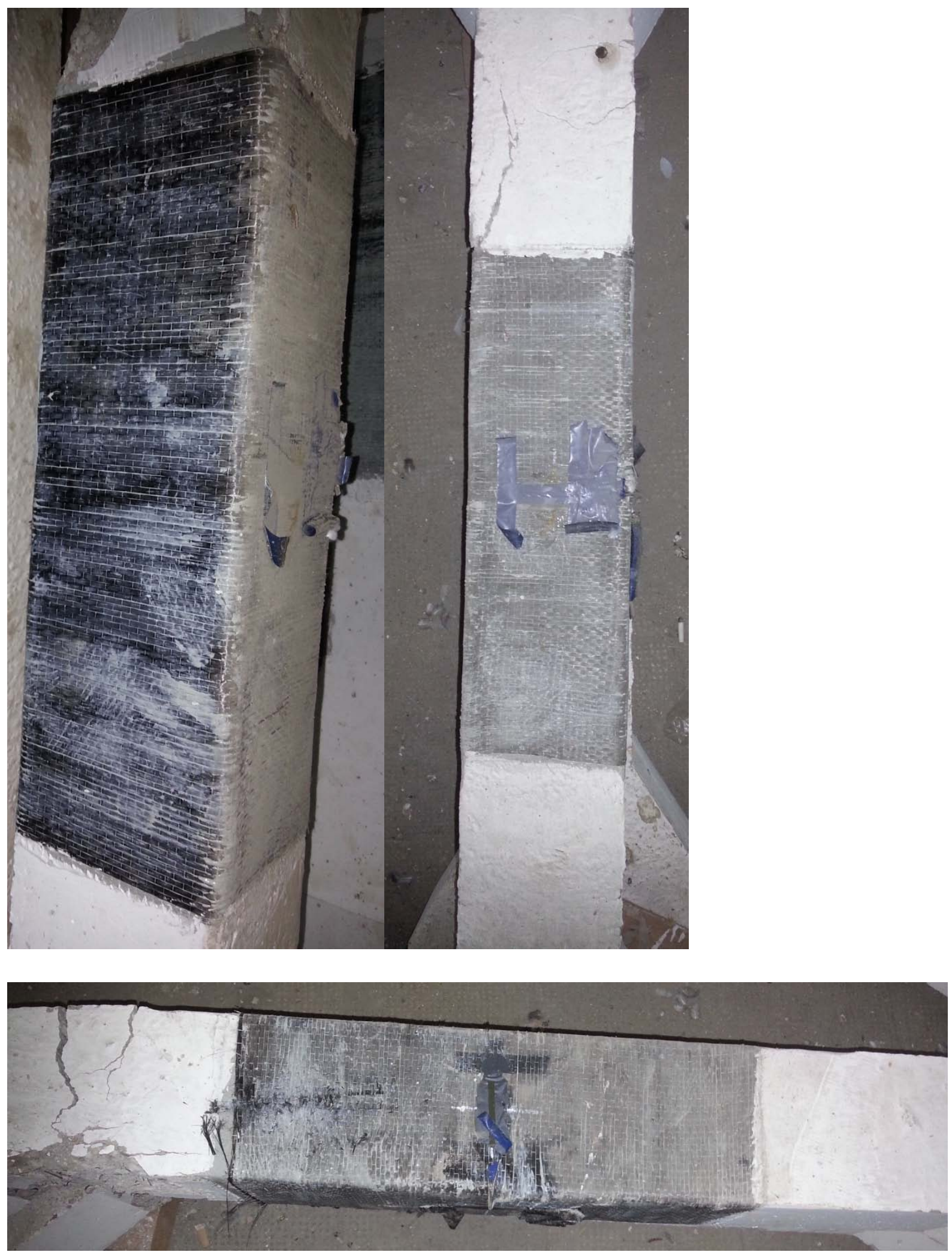

Photo (12) Mode of Failure for one of the enhanced specimens) 